\title{
World Health Day 2021: Amidst the Backdrop of COVID-19
}

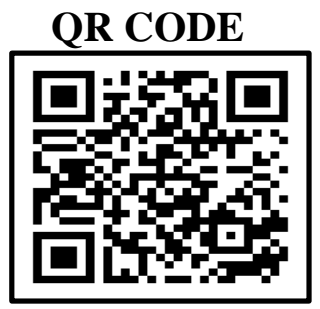

\section{RASHMI JAISWAL}

The world is currently going through a situation where we can see rising deaths due to COVID-19. If these records continue to hike in the same manner, then the day is not so far when, we will contribute to this and take this list further. With an already strained healthcare system across the globe, all countries are plagued by the emergence of the various waves of the pandemic. With the target to vaccinate the entire global population, the World Health Day 2021 with the theme "Building a Fairer, Healthier World" offers hope for a better, COVID-19 free world.

\section{KEYWORDS: COVID-19, Health, WHO}

\section{INTRODUCTION}

The World Health Organisation's (WHO) constitution was implemented worldwide on $7^{\text {th }}$ April, 1950. Since then, the same day is celebrated as "World Health Day" globally." The significance behind marking this day is to spread awareness and make people realise the importance of leading a healthy and stable life. This day mainly emphasizes on drawing attention towards the subject of global health. Today the entire world is concerned about health and lifestyle. Only reason behind this being the recognition of health and diseases escalated throughout the mankind by WHO. During the earlier times when there was no such awareness, people had to suffer dreadfully from chronic diseases without even knowing the cause and cure. ${ }^{2}$

\section{HISTORY OF PANDEMICS (POST 2000) ${ }^{3}$}

Pandemic is a worldwide spread of a disease. It's an unfortunate reality, but this has happened quite very often in the past. Addressing the $21^{\text {st }}$ century, some of the major pandemics have occurred that demolished many lives.

\section{SEVERE ACUTE RESPIRATORY} SYNDROME/SARS (2002): First reported in November 2002 in China. It is caused by SARS-CoV. WHO reported 8,096 cases and 774 deaths.

Swine Flu/H1Nı Flu (2009): It was noted for its rapid global spread because of high degree of viral contagiousness. It was first detected in United States in April, 2009. CDC estimated that 151,700-575,400 people worldwide died from this disease.

Middle East Respiratory Syndrome/ MERS (2012): It was first observed in June 2012 in Saudi Arabia. It is caused by MERS-CoV which attacks the respiratory system. In total, 27 countries have reported cases, leading to 858 known deaths.

EBOLA (2014): Ebola outbreak was first reported in March 2014 in West Africa. It was noted for its unprecedented magnitude. The outbreak ended with more than 28,600 cases and 11,325 deaths (as reported by $\mathrm{CDC})$.

\section{ROLE OF WHO DURING COVID-19 PANDEMIC 4}

Dr. Tedros Adhanom, Director General of the World Health Organization once said "A devastating epidemic can start in any country, at any time and kill millions of people because we are not prepared. We are still vulnerable." (12 ${ }^{\text {th }}$ February, 2018)

A cluster of pneumonia cases was reported in Wuhan, post which WHO activated the emergency management team on 1st January, 2020. As a response to increasing cases, WHO launched the R\&D blueprint on diagnostics, vaccines \& therapeutics for the novel coronavirus. The main sight was to improve 
coordination between scientists and global health professionals for global research on corona virus disease. However, many allegations were raised on WHO's credentials for its dereliction of duty for covering up China's failure to handle the crisis.

WHO issued an advisory stating the best way out of this pandemic would be comprehensive approach. WHO suggested all countries to perform maximum possible testing and contact tracing. They suggested to follow social distancing to break the chain of spread.

\section{WORLD HEALTH DAY 2021 ${ }^{1}$}

"Building a Fairer, Healthier World" is a very serious and impactful theme chosen by WHO for this year's World Health Day. Poor and underprivileged people are the first victim of any pandemic as they are unable to avail the proper medical facilities and necessary services at the right time. Which is not fair enough, since we all are equal and should have equal exposure to all medical facilities. On the occasion of world health day, promotional programs, events and activities are launched worldwide to forecast the awareness related to public health. We need to work all together, to tackle this issue and achieve the motive behind this theme.

\section{REFERENCES}

1. WHO. World Health Day. (Online Article). Available from: https://www.who.int/westernpacific/news/events/wor ld-health-day [Last Accessed on $15^{\text {th }}$ January, 2021] 2. Singh AR, Singh SA. Diseases of Poverty and Lifestyle, Well-Being and Human Development. Mens Sana Monogr. 2008; 6(1): 187-225. https://doi.org/10.4103/0973-1229.40567

3. Huremović D. Brief History of Pandemics (Pandemics Throughout History). Psychiatry of Pandemics 2019:7-35. https://doi.org/10.1007/978-3030-15346-5_2

4. UN News. 5 reasons the world needs WHO, to fight the COVID-19 pandemic. (Online Article). Available from: https://news.un.org/en/story/2020/04/1061412 [Last Accessed on $15^{\text {th }}$ January, 2021] 